Provided for non-commercial research and education use. Not for reproduction, distribution or commercial use.

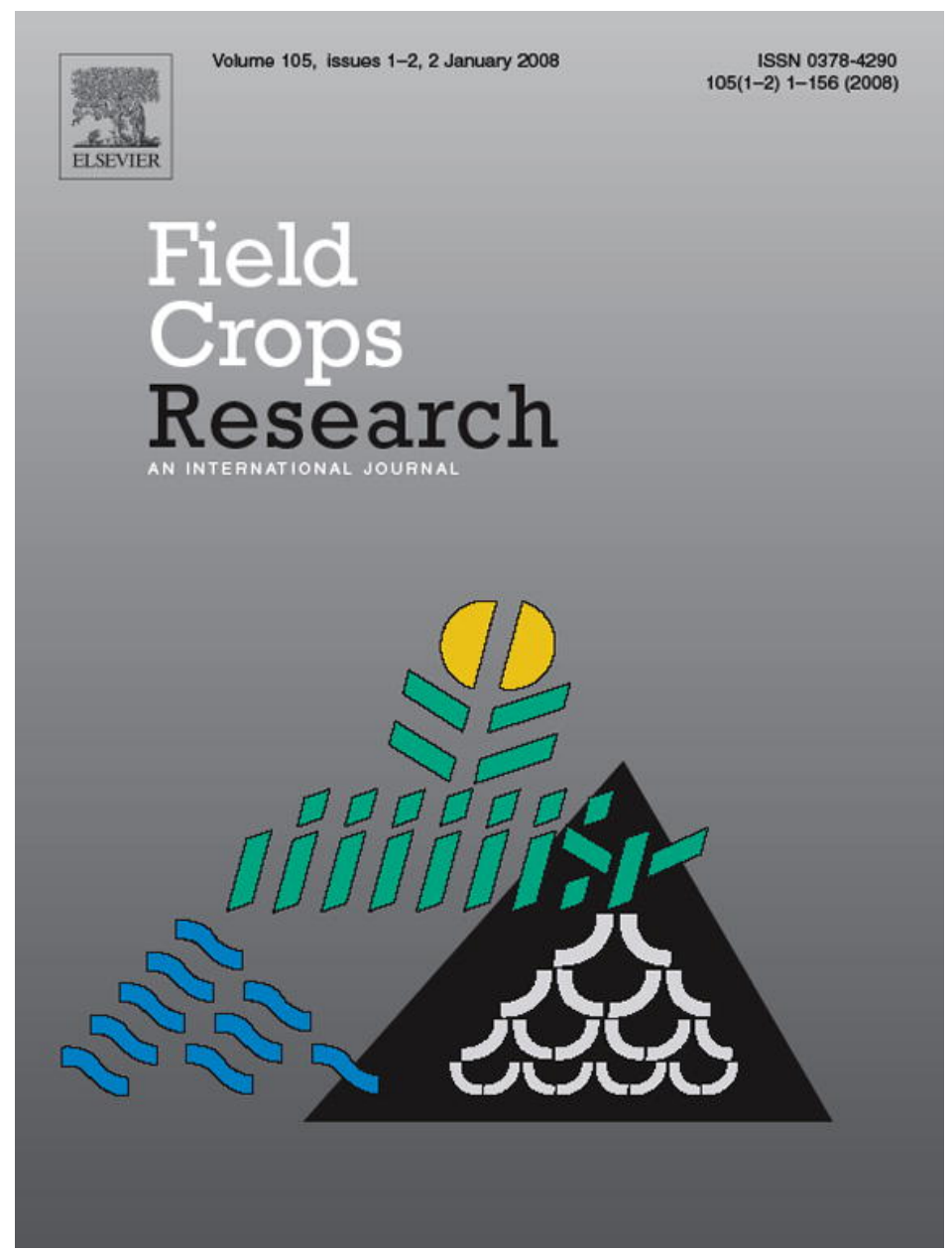

This article was published in an Elsevier journal. The attached copy

is furnished to the author for non-commercial research and education use, including for instruction at the author's institution, sharing with colleagues and providing to institution administration.

Other uses, including reproduction and distribution, or selling or licensing copies, or posting to personal, institutional or third party websites are prohibited.

In most cases authors are permitted to post their version of the article (e.g. in Word or Tex form) to their personal website or institutional repository. Authors requiring further information regarding Elsevier's archiving and manuscript policies are encouraged to visit:

http://www.elsevier.com/copyright 


\title{
Estimation of gene effects of the drought avoidance root characteristics in chickpea (C. arietinum L.)
}

\author{
J. Kashiwagi *, L. Krishnamurthy, P.M. Gaur, S. Chandra, H.D. Upadhyaya \\ International Crops Research Institute for the Semi-Arid Tropics, Patancheru 502324, Andhra Pradesh, India \\ Received 23 July 2007; accepted 24 July 2007
}

\begin{abstract}
The productivity of chickpea (C. arietinum L.) in the arid and semi-arid regions is constrained due to terminal drought. Chickpea genotypes with prolific and deep rooting have been shown to be more adapted to drought but little information is available on the genetic control of root system. The genetic components that govern the expression of root and shoot characteristics were investigated through generation mean analysis, using six generations $\left(\mathrm{P}_{1}, \mathrm{P}_{2}, \mathrm{~F}_{1}, \mathrm{~F}_{2}, \mathrm{BC}_{1} \mathrm{P}_{1}\right.$ and $\left.\mathrm{BC}_{1} \mathrm{P}_{2}\right)$ of two crosses (ICC $283 \times$ ICC 8261 and ICC $4958 \times$ ICC 1882) in chickpea involving parents with contrasting root characteristics. In both the crosses, the additive and additive $\times$ additive interaction effects played important role in governing the root length density and root dry weight. The direction of the additive gene effects was consistent and towards increasing the root growth. Delaying selections to later generations and generating larger populations for selections were proposed as strategies for improving root systems of chickpea to exploit additive $\times$ additive interaction.
\end{abstract}

(C) 2007 Elsevier B.V. All rights reserved.

Keywords: Breeding; Gene effects; Joint scale test; Root characteristics; Chickpea

\section{Introduction}

Chickpea (Cicer arietinum L.) is the world's third largest food legume crop with a total annual production of 8.8 million tons. The cultivated area is over 10 million hectares (FAO, 2007). It is cultivated in about 50 countries in the arid or semiarid regions. About $90 \%$ of world's chickpea is grown under rainfed conditions (Kumar and Abbo, 2001) where the crop grows and matures on a progressively depleting soil moisture profile (Ludlow and Muchow, 1990; Krishnamurthy et al., 1999) and generally experiences terminal drought. Terminal drought is, therefore, one of the major constraints limiting chickpea productivity and yield stability.

In the last decade, the main breeding strategy used to cope with the terminal drought in chickpea was selecting for drought escape by reducing the crop duration and securing the seed yield before soil water was depleted. This strategy was successful in increasing yield stability and resulted in release of early maturing varieties, e.g. ICCV 2, with good adoption by farmers (Kumar et al., 2001). However, the early maturing

\footnotetext{
* Corresponding author. Tel.: +91 40 30713327; fax: +91 40 30713074/75 E-mail address: J.Kashiwagi@cgiar.org (J. Kashiwagi).
}

varieties had relatively lower biomass and seed yield mainly due to a shortened total photosynthetic duration. Thus, as a long-term strategy, there is a need to develop drought-tolerant genotypes that could optimally utilize the available season for an enhanced yield and its stability under terminal drought stress. Such breeding strategy for direct yield has been successful in some crops; e.g. rice (Fukai and Cooper, 1995), common bean (Schneider et al., 1997; Frahm et al., 2004) and maize (Banziger et al., 1999). Also in chickpea, some drought tolerant genotypes, including ICC 4958, have been identified by screening more than 1500 germplasm accessions directly for yields under drought conditions over a period of time (Saxena et al., 1993; Saxena, 2003). However, evaluation of these genotypes under a gradient of soil moisture environments created through line-source sprinkler system had shown that there were large genotype $\times$ soil moisture interactions and the tested genotypes fell into four distinct groups for the type of drought response (Johansen et al., 1994).

Subsequent research showed that large root system, among many other mechanisms of drought tolerance, was one of the major traits conferring seed yield advantage (Saxena et al., 1993; Saxena and Johansen, 1990). The genotype ICC 4958, with $30 \%$ more root weight than the standard cultivar Annigeri, was the best yielder under severe drought environments 
(Saxena, 1987). Thus, the approach of improving drought tolerance by enhanced soil water absorption by the root systems seems promising for growing of even relatively longer duration varieties. In grain legumes, large genotypic variation in rooting depth and ability to extract water at depth has been shown to affect the seed yield through better water acquisition and increased transpiration efficiency (TE) as in case of peanut (Ketring, 1984; Mathews et al., 1988; Wright et al., 1991), soybean (Cortes and Sinclair, 1986), common bean (White and Castillo, 1988) and chickpea (Kashiwagi et al., 2006). In pigeonpea, shallow root systems in many high-yielding shortduration crop varieties have been shown to be the cause of susceptibility to rapid onset of terminal drought (Subbarao et al., 2000).

Despite the recognition of the importance of the root characteristics, large-scale breeding programs for the root characteristics improvement in chickpea has been limited due to the lack of knowledge on the genetic diversity and genetics of root characteristics (Saxena et al., 1995; Saxena, 2003). In a recent study, a large genetic diversity was observed for root characteristics in chickpea mini-core germplasm collection $(n=211)$ (Kashiwagi et al., 2005) that represents considerable diversity of the entire chickpea germplasm collection held at ICRISAT ( $n=16,991)$ (Upadhyaya and Ortiz, 2001; Upadhyaya et al., 2001). The genotypes ICC 8261 and ICC 4958 showed large and prolific root systems while ICC 1882 and ICC 283 had small and less prolific root systems in the mini-core collection. Compared to the progress on genetic diversity of root characteristics, the available information on genetics of root characteristics is still very limited except for some reports on heritability estimates (Krishnamurthy et al., 2004; Kashiwagi et al., 2005).

The objective of this study was to estimate the gene effects for the expression of root characteristics in chickpea and to propose a breeding strategy for selection of plants with root characteristics that improve the drought avoidance.

\section{Materials and methods}

Two germplasm accessions, ICC 8261 and ICC 4958, showing prolific and deep root system, and two, ICC 283 and ICC 1882, with least prolific and shallow root system, were selected from chickpea mini-core collection based upon the previous studies (Kashiwagi et al., 2005). Two crosses were made between parents with closest possible duration; one between ICC 283 (maturing at 88 days under non-irrigated condition) and ICC 8261 (88 days), and the other between ICC 4958 (80 days) and ICC 1882 (87 days). The genotype with a prolific and deep root system was used as male parent $\left(\mathrm{P}_{2}\right)$ in the first cross (ICC $283 \times$ ICC 8261$)$ and as a female parent $\left(\mathrm{P}_{1}\right)$ in the second cross (ICC $4958 \times$ ICC 1882). Six generations, viz., $\mathrm{P}_{1}$ (ICC 283 or ICC 4958), $\mathrm{P}_{2}$ (ICC 8261 or ICC 1882), $\mathrm{F}_{1}, \mathrm{~F}_{2}$, and two backcrosses $\left[\mathrm{BC}_{1} \mathrm{P}_{1}\left(\mathrm{~F}_{1} \times \mathrm{P}_{1}\right)\right.$ and $\left.\mathrm{BC}_{1} \mathrm{P}_{2}\left(\mathrm{~F}_{1} \times \mathrm{P}_{2}\right)\right]$, of the two crosses were included in this study. The experiment was conducted in a completely randomized block design during 2003/04 post-rainy season in open field conditions at International Crops Research Institute for the Semi-Arid
Tropics (ICRISAT), Patancheru $\left(17^{\circ} 30^{\prime} \mathrm{N} ; 78^{\circ} 16^{\prime} \mathrm{E}\right.$; altitude $549 \mathrm{~m})$. Forty-eight seeds each for $\mathrm{P}_{1}, \mathrm{P}_{2}$ and $\mathrm{F}_{1}$ generation; 96 seeds each for the two backcross generations; and 288 seeds each for $\mathrm{F}_{2}$ generations were sown in tall PVC cylinders with $18 \mathrm{~cm}$ diameter and $120 \mathrm{~cm}$ height filled with soil-sand mixture $(1: 1, w / w)$ watered to $70 \%$ field capacity. One plant per cylinder was grown and was irrigated with $150 \mathrm{ml}$ of water on $3 \mathrm{rd}$ and 5 th day after sowing to ensure uniform emergence. After that, no irrigation was given so as to create the terminal drought conditions and to broadly mimic the field conditions. The plants were protected from rainfall by using a movable rain-out shelter during rains.

Plants were sampled at 35 days after sowing (DAS) avoiding physically damaged plants, as previous studies showed that maximum variation in root dry weight and root length density among genotypes are best noticed in this environment at this stage, and that variation is reduced after 41 DAS (Krishnamurthy et al., 1996). After harvesting the shoots, the cylinders were placed horizontally and the sand-soil mixture was removed gently with the help of running water. When approximately three-quarters of the filled soil-sand mixture was washed away, the cylinder was erected gently on a sieve so that the whole intact root system could be easily slipped down. After removing the soil particles under running water, the root systems were straightened to estimate the maximum rooting depth, and then using an image analysis system (WinRhizo, Regent Instruments INC., Quebec, Canada) the total root length was measured. The root length density (RLD) was calculated by dividing the total root length per cylinder by the cylinder volume at the maximum rooting depth. The shoot and root dry weights (SDW, RDW) were recorded after drying in a hot air oven at $80{ }^{\circ} \mathrm{C}$ for $72 \mathrm{~h}$. The RLD is an indicator of the capability for soil water exploitation, while RDW shows the biomass of root systems. Two ratios, the root to total plant dry weight ratio $(R / T)$ that indicates the relative root biomass distribution, and the ratio of RLD below $60 \mathrm{~cm}$ depth to the total RLD that indicates deep rooting index (DRI), were calculated.

Statistical analyses were performed using GenStat 9th Edition (GenStat, 2006). A joint scaling test (Cavalli, 1952) was conducted to estimate the genetic components and digenic interactions, viz., $m$ (mean), [d] (pooled additive effects), [h] (pooled dominant effects), [i] (pooled additive $\times$ additive effects), [j] (pooled additive $\times$ dominance effects) and [1] (pooled dominance $\times$ dominance effects). Then, stepwise regression analysis was used to find the best-fit model as suggested by Torres et al. (1993). The standard error of $m$ and each of five genetic components was computed for testing the significance of each parameter by $t$-test. The percentage of each five component to overall model sum of squares was calculated to determine the relative importance of each component.

\section{Results}

The analysis of variance revealed the significant differences among the parents and progenies for all the root and shoot characteristics in both the crosses (Table 1). As observed in previous studies (Kashiwagi et al., 2005), accessions ICC 8261 


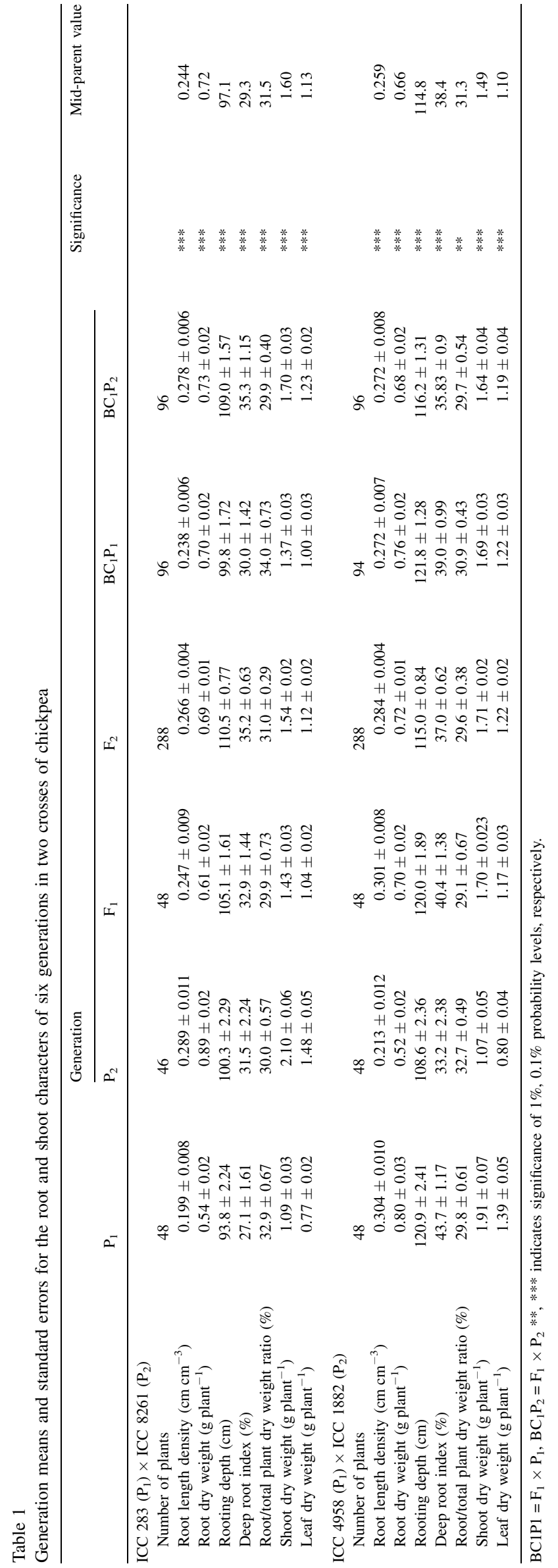

and ICC 4958 showed greater root and shoot growth compared to ICC 283 and ICC 1882. In both the crosses, the shoot dry weight (SDW) and leaf dry weight (LDW) showed large differences between the parental lines. The differences were almost double. Also, the root length density and root dry weight (RDW) showed substantial differences with approximately 1.5 times greater values for the better parent. This indicated that the choice of parents was appropriate. On the other hand, the difference in root to total plant dry weight ratio, and rooting depth (RDp), deep rooting index between the parental lines was relatively narrow in both the crosses.

The distribution of means of each generation on the root characteristics, RLD, showed that the means of F1 and F2 generations fell between parental means in ICC $283 \times$ ICC 8261, whereas in ICC $4958 \times$ ICC 1882 only the F2 fell between parental means while the F1 mean was close to the P1 mean (Table 1). The mean RLD for the F1 generation $\left(0.247 \mathrm{~cm} \mathrm{~cm}^{-3}\right)$ in ICC $283 \times$ ICC 8261 was similar to the mid parental value $\left(0.244 \mathrm{~cm} \mathrm{~cm}^{-3}\right)$, on the other hand in ICC $4958 \times$ ICC 1882 it was $16.4 \%$ greater $\left(0.301 \mathrm{~cm} \mathrm{~cm}^{-3}\right)$ than the mid parent value $\left(0.259 \mathrm{~cm} \mathrm{~cm}^{-3}\right)$ indicating the absence of complete dominance. The mean RLD of F2 generation was higher than that of the F1 generation in ICC $283 \times$ ICC 8261 , whereas smaller in ICC $4958 \times$ ICC 1882 . The backcross means were between the $\mathrm{F} 1$ and the recurrent parent means in ICC $283 \times$ ICC 8261 , but in ICC $4958 \times$ ICC 1882 the BC1P1 mean was smaller than P1 and F1 generation means. As for the distribution of RDW means, the F1 and F2 generations were intermediate between the means of P1 and P2 in both crosses (Table 1). The RDW means of the F1 generation in relation to the mid parental values was different in each cross; F1 mean was lower than the mid parental value in ICC $283 \times$ ICC 8261 , whereas it was higher than the mid parental value in ICC $4958 \times$ ICC 1882 . The F2 mean was higher than that of F1 generation in both crosses. The backcross means were between the F1 and the recurrent parent means in ICC $4958 \times$ ICC 1882 but not in ICC $283 \times$ ICC 8261 for BC1P1. These results indicate that varying relative importance of dominance deviation and additive effects on RLD and RDW in both crosses.

The regression analysis tested different parameter to find the best-fit model to explain genetic control on the five root and two shoot characteristics. For RLD, the model including additive [d] effect as well as two epistatic interactions, [i], [1] showed the best fit to the data in both ICC $283 \times$ ICC 8261 and ICC $4958 \times$ ICC 1882 (Table 2). In both the crosses, the [d] effect was significant $(p=0.05)$ and the direction of gene effect was consistently toward increasing RLD. The [d] effect accounted for $24.8 \%$ of genetic variability for RLD in ICC $283 \times$ ICC 8261 and $60.3 \%$ in ICC $4958 \times$ ICC 1882 (Table 3). In addition, the [i] epistatic effects, which are genetically fixable and can be exploited in a self-pollinated crop such as chickpea, were also detected $(p=0.05)$ and accounted for $37.9 \%$ of genetic variability in ICC $283 \times$ ICC 8261 and $4.3 \%$ in ICC $4958 \times$ ICC 1882 for RLD. The interallelic [1] interaction was also observed in both crosses but the contribution for RLD was very small $(1.4 \%$ in ICC $283 \times$ ICC 8261 , and $0.9 \%$ in ICC 
Table 2

Estimates of gene effects for the root and shoot characters of six generations in two crosses of chickpea

\begin{tabular}{|c|c|c|c|c|c|c|c|}
\hline & Root length density & $\begin{array}{l}\text { Root dry } \\
\text { weight }\end{array}$ & Rooting depth & $\begin{array}{l}\text { Deep root } \\
\text { index }\end{array}$ & $\begin{array}{l}\text { Root /total plant } \\
\text { dry weight ratio }\end{array}$ & $\begin{array}{l}\text { Shoot dry } \\
\text { weight }\end{array}$ & $\begin{array}{l}\text { Leaf dry } \\
\text { weight }\end{array}$ \\
\hline \multicolumn{8}{|c|}{ ICC $283\left(\mathrm{P}_{1}\right) \times \operatorname{ICC} 8261\left(\mathrm{P}_{2}\right)$} \\
\hline$m$ & $0.225 \pm 0.004$ & $0.78 \pm 0.01$ & $103.97 \pm 6.04$ & $36.57 \pm 1.09$ & $30.58 \pm 0.26$ & $2.12 \pm 0.15$ & $1.43 \pm 0.05$ \\
\hline [d] & $-0.012 \pm 0.004$ & $-0.12 \pm 0.01$ & $3.18 \pm 1.15$ & $1.17 \pm 1.03$ & $0.37 \pm 0.36$ & $-0.18 \pm 0.02$ & $-0.15 \pm 0.02$ \\
\hline$[\mathrm{h}]$ & ns & ns & $19.00 \pm 14.10$ & ns & ns & $-0.97 \pm 0.34$ & $-0.39 \pm 0.07$ \\
\hline [i] & $-0.048 \pm 0.006$ & $-0.08 \pm 0.02$ & $-6.86 \pm 5.90$ & $-7.69 \pm 1.92$ & $1.07 \pm 0.57$ & $-0.74 \pm 0.15$ & $-0.44 \pm 0.05$ \\
\hline [j] & ns & ns & ns & ns & ns & ns & ns \\
\hline$[1]$ & $-0.040 \pm 0.007$ & $-0.17 \pm 0.03$ & $-17.74 \pm 8.67$ & $-3.43 \pm 2.03$ & ns & $0.28 \pm 0.21$ & ns \\
\hline \multicolumn{8}{|c|}{ ICC $4958\left(\mathrm{P}_{1}\right) \times \operatorname{ICC} 1882\left(\mathrm{P}_{2}\right)$} \\
\hline$m$ & $0.213 \pm 0.004$ & $0.71 \pm 0.01$ & $114.43 \pm 1.33$ & $33.95 \pm 1.00$ & $29.72 \pm 0.28$ & $1.70 \pm 0.02$ & $1.05 \pm 0.03$ \\
\hline [d] & $0.032 \pm 0.003$ & $0.08 \pm 0.01$ & ns & $1.11 \pm 0.87$ & $-1.39 \pm 0.32$ & $0.21 \pm 0.03$ & $0.14 \pm 0.02$ \\
\hline$[\mathrm{h}]$ & ns & ns & $5.29 \pm 2.47$ & ns & ns & ns & $0.42 \pm 0.11$ \\
\hline [i] & $0.010 \pm 0.006$ & $-0.05 \pm 0.02$ & ns & $7.06 \pm 1.67$ & $1.59 \pm 0.53$ & $-0.24 \pm 0.05$ & $\mathrm{~ns}$ \\
\hline [j] & ns & ns & ns & ns & ns & $\mathrm{ns}$ & ns \\
\hline$[1]$ & $0.032 \pm 0.010$ & ns & ns & $6.65 \pm 1.96$ & ns & ns & $-0.29 \pm 0.10$ \\
\hline
\end{tabular}

$4958 \times$ ICC 1882) (Table 3). For RDW, a significant [d] effect was observed $(p=0.05)$ and the direction of which was toward increasing RDW in both crosses (Table 2). It accounted for $54.7 \%$ of genetic variability in RDW in ICC $283 \times$ ICC 8261 and $42.8 \%$ in ICC $4958 \times$ ICC 1882 . A significant [i] effect also could be seen in both crosses that accounted for $11.7 \%$ for RDW in ICC $283 \times$ ICC 8261 . Although the direction of the [i] effect in ICC $4958 \times$ ICC 1882 was toward reducing RDW it accounted for only $0.4 \%$ for RDW.

For RDp in ICC $283 \times$ ICC 8261 , significant [d] was detected but the direction of the gene effect was toward reducing the rooting depth (Table 2). The contribution of [d] effect to RDp, however, was small at $5.4 \%$ (Table 3). The [i] effect was more important and accounted for $29.2 \%$ of the genetic variation in RDp. The contribution of [1] effect was too small $(0.1 \%)$. On the other hand, in ICC $4958 \times$ ICC 1882 only dominance effect was significant (Table 2) and accounted for $11.4 \%$ for RDp (Table 3). DRI showed inconsistent direction of the [d] effect in each cross, viz., toward reducing DRI in ICC $283 \times$ ICC 8261and increasing DRI in ICC $4958 \times$ ICC 1882 (Table 2). However, the contributions of [d] for DRI were not so substantial $(0.3 \%$ in ICC $283 \times$ ICC 8261 , and $14.8 \%$ in ICC
$4958 \times$ ICC 1882) (Table 3). In both crosses the [i] effect for DRI was more important as it accounted for $36.3 \%$ in ICC $283 \times$ ICC 8261 and $40.4 \%$ in ICC $4958 \times$ ICC 1882 (Table 3), and the direction of the [i] was consistently toward increasing DRI in both crosses (Table 2). The results showed that [d] effect seemed to be genotype-specific.

For $R / T$, there was a significant [d] effect toward increasing relative dry matter accumulation to root systems (Table 2 ). The [d] effect accounted for $70.0 \%$ of $R / T$ in ICC $4958 \times$ ICC 1882 but only $1.8 \%$ in ICC $283 \times$ ICC 8261 (Table 3 ). The [i] effect towards reducing $R / T$ was detected but the contribution for $R / T$ was small $(3.5 \%$ in ICC $283 \times$ ICC 8261 , and $1.4 \%$ in ICC $4958 \times$ ICC 1882) (Table 3$)$.

For plant growth vigor indicated by SDW, a significant [d] effect was observed in both crosses $(p=0.05)$ and the direction of the gene effect was consistently towards facilitating the plant growth vigor (Table 2). The [d] effect accounted for the largest portion of genetic variability for SDW in both crosses $(34.3 \%$ in ICC $283 \times$ ICC 8261 , and $48.9 \%$ in ICC $4958 \times$ ICC 1882) (Table 3). In LDW, the contribution from [d] effect was the largest in both crosses $(40.3 \%$ in ICC $283 \times$ ICC 8261 , and $53.9 \%$ in ICC $4958 \times$ ICC 1882) (Table 3 ) and the direction of

Table 3

Variability accounted for by the different components for the root and shoot characters of six generations in two crosses of chickpea

\begin{tabular}{|c|c|c|c|c|c|c|c|}
\hline & Root length density & $\begin{array}{l}\text { Root dry } \\
\text { weight }\end{array}$ & $\begin{array}{l}\text { Rooting } \\
\text { depth }\end{array}$ & $\begin{array}{l}\text { Deep root } \\
\text { index }\end{array}$ & $\begin{array}{l}\text { Root/total plant } \\
\text { dry weight ratio }\end{array}$ & $\begin{array}{l}\text { Shoot dry } \\
\text { weight }\end{array}$ & $\begin{array}{l}\text { Leaf dry } \\
\text { weight }\end{array}$ \\
\hline \multicolumn{8}{|c|}{ ICC $283\left(\mathrm{P}_{1}\right) \times \operatorname{ICC} 8261\left(\mathrm{P}_{2}\right)$} \\
\hline [d] & 24.8 & 54.7 & 5.4 & 0.3 & 1.8 & 34.3 & 40.3 \\
\hline$[\mathrm{h}]$ & ns & ns & 11.3 & ns & ns & 0.9 & 1.6 \\
\hline$[\mathrm{I}]$ & 37.9 & 11.7 & 29.2 & 36.3 & 3.5 & 15.0 & 17.0 \\
\hline$[\mathrm{j}]$ & ns & ns & ns & ns & ns & ns & ns \\
\hline$[1]$ & 1.4 & 0.01 & 0.1 & 1.9 & ns & 7.9 & ns \\
\hline \multicolumn{8}{|c|}{ ICC $4958\left(\mathrm{P}_{1}\right) \times \operatorname{ICC} 1882\left(\mathrm{P}_{2}\right)$} \\
\hline [d] & 60.3 & 42.8 & ns & 14.8 & 70.0 & 48.9 & 53.9 \\
\hline$[\mathrm{h}]$ & ns & ns & 11.4 & ns & ns & ns & 5.3 \\
\hline [i] & 4.3 & 0.4 & ns & 40.4 & 1.4 & 3.2 & $\mathrm{~ns}$ \\
\hline [j] & ns & ns & ns & ns & ns & ns & $\mathrm{ns}$ \\
\hline [1] & 0.9 & ns & ns & 0.3 & $\mathrm{~ns}$ & ns & 5.0 \\
\hline
\end{tabular}


[d] was toward increasing the LDW in both crosses $(-0.15$ in ICC $283 \times$ ICC 8261 , and 0.14 in ICC $4958 \times$ ICC 1882 (Table 2).

\section{Discussion}

The important findings of this study are the major contribution of the additive and additive $\times$ additive gene effect in the root biomass (RDW) as well as root length density, the consistent direction of the gene effects toward increasing the root growth and the closeness of genetic control between root dry weight and shoot dry weight. These results have close resemblances to gene components that control the expression of root dry weight and root surface area in common bean (Araujo et al., 2005). Also in cotton, the gene effects of root characteristics showed that additive and additive $\times$ additive gene effects account for about $50 \%$ of the variation in root length in one of the two crosses tested at seedling stage (Eissa et al., 1983).

These results have implication for breeding and selection of improved root growth and the consequent water supply. For the traits showing additive $\times$ additive epistasis, the procedure of selection should be modified to exploit their interallelic interaction. This includes selection in later generations and maintenance of large populations prior to selection to provide maximum opportunity for advantageous combination of genes to occur (Upadhyaya and Nigam, 1998). Early generation selection would be less effective. Maintenance of large populations could be particularly necessary when exotic germplasm are included in breeding programs because in the adapted and exotic crosses segregating loci are expected to be more as the number of homozygote genotypes in a segregating population is a geometric function of number of segregating loci. Further, in studies involving adapted and exotic crosses, it is advantageous to backcross one or more times with recurrent parent before selection to enhance the probability of obtaining superior lines (Dudley, 1982). As it is practically impossible to investigate the larger population for RLD and RDW screening, marker assisted selection need to be sought for proper screening of these characteristics.

In chickpea, the rooting depth is also an important characteristic to improve the drought tolerance (Kashiwagi et al., 2006). Deeper rooting (RDp and DRI) showed different gene effects compared to RLD or RDW, that is, the additive effect for deeper rooting (RDp and DRI) seemed to be genotype-specific. This suggests that proper cross combination need to be selected for deeper rooting improvement. The possibility of breeding for deep rooting seems to be bright as indicated by substantial fixable additive $\times$ additive gene effects on DRI in both crosses and for RDp only in ICC $4958 \times$ ICC 1882. Therefore, breeding for both DRI and RDp is expected to take longer time and to be more challenging compared to that of RLD and RDW in chickpea.

Both shoot and leaf growth were mainly affected by the additive effects and to some extent by the additive $\times$ additive effects with the direction of the gene effects consistently towards enhancing the shoot growth. In a previous study, the plant height in chickpea was shown to be predominantly under additive gene effect (Singh et al., 1992). Early shoot growth vigor is another important trait which contributes to terminal drought tolerance in chickpea (Saxena and Johansen, 1990; Turner et al., 2001). As genetic control of shoot growth of chickpea is more or less similar to that of RLD and RDW in this trial, breeding procedure suggested for RLD and RDW are also applicable to breed and select for shoot growth vigor.

\section{Conclusion}

Additive as well as the additive $\times$ additive epistasis affected the expression of root growth, viz., root length density and root dry weight, in two crosses. The direction of the additive gene effects was consistent and towards increasing root growth. Therefore, delaying the selection to later generations by maintaining larger populations could be proposed as the best breeding strategy for improving the root growth. Considering the difficulties in selection for root traits, marker-assisted selection is proposed to be more appropriate route for genetic improvement of root traits in chickpea.

\section{Acknowledgement}

This research was partly supported by the unrestricted funds from the Japanese Government earmarked for chickpea drought tolerance research and breeding in ICRISAT.

\section{References}

Araujo, A.P., Antunes, I.F., Teixeira, M.G., 2005. Inheritance of root traits and phosphorus uptake in common bean (Phaseolus vulgaris L.) under limited soil phosphorus supply. Euphytica 145, 33-40.

Banziger, M., Edmeades, G.O., Lafitte, H.R., 1999. Selection for drought tolerance increases maize yields across a range of nitrogen levels. Crop Sci. 39, 1035-1040.

Cavalli, L.L., 1952. An analysis of linkage in quantitative inheritance. In: Reeve, E.C.R., Waddington, C.H. (Eds.), Quantitative Inheritance. MHSO, London, pp. 35-144.

Cortes, P.M., Sinclair, T.R., 1986. Water relations of field grown soybean under drought. Crop Sci. 26, 993-998.

Dudley, J.W., 1982. Theory for transfer of alleles. Crop Sci. 22, 631-635.

Eissa, A.M., Jenkins, J.N., Vaughan, C.E., 1983. Inheritance of seedling root length and relative root weight in cotton. Crop Sci. 23, 1107-1111.

Food and Agricultural Organization of the United Nations, 2007. FAO Statistical Databases. FAO, Rome available at http://faostat.fao.org/site/340/ default.aspx.

Frahm, M.A., Rosas, J.C., Mayek-Perez, N., Lopez-Salinas, E., Acosta-Gallegos, J.A., Kelly, J.D., 2004. Breeding beans for resistance to terminal drought in the lowland tropics. Euphytica 136, 223-232.

Fukai, S., Cooper, M., 1995. Development of drought-resistant cultivars using physio-morphological traits in rice. Field Crops Res. 40, 67-86.

Johansen, C., Krishnamurthy, L., Saxena, N.P., Sethi, S.C., 1994. Genotypic variation in moisture response of chickpea grown under line-source sprinklers in a semi-arid tropical environment. Field Crops Res. 37, 103-112.

Kashiwagi, J., Krishnamurthy, L., Crouch, J.H., Serraj, R., 2006. Variability of root characteristics and their contributions to seed yield in chickpea (Cicer arietinum L) under terminal drought stress. Field Crops Res. 95, 171-181.

Kashiwagi, J., Krishnamurthy, L., Upadhyaya, H.D., Krishna, H., Chandra, S., Vadez, V., Serraj, R., 2005. Genetic variability of drought-avoidance root traits in the mini-core germplasm collection of chickpea (Cicer arietinum L.). Euphytica 146, 213-222. 
Ketring, D.L., 1984. Root diversity among peanut genotypes. Crop Sci. 24, 229232.

Krishnamurthy, L., Johansen, C., Ito, O., 1996. Genetic variation in root system development and its implications for drought resistance in chickpea. In: Ito, O., Johansen, C., Adu-Gyamfi, J.J., Katayama, K., Kumar Rao, J.V.D.K., Rego, T.J. (Eds.), Root and Nitrogen in cropping Systems of the Semi-arid Tropics. Culio Corporation, Tsukuba, Japan, pp. 234250 .

Krishnamurthy, L., Johansen, C., Sethi, S.C., 1999. Investigation of factors determining genotypic differences in seed yield of non-irrigated and irrigated chickpeas using a physiological model of yield determination. J. Agron. Crop Sci. 183, 9-17.

Krishnamurthy, L., Serraj, R., Kashiwagi, J., Panwar, J.D.S., Koteswara Rao, Y., Kumar, J., 2004. Multilocation analysis of yield and yield components of chickpea mapping population grown under terminal drought. Indian J. Pulses Res. 17, 17-24.

Kumar, J., Abbo, S., 2001. Genetics of flowering time in chickpea and its bearing on productivity in semiarid environments. Adv. Agron. 72, 122124.

Kumar, J., Pannu, R.K., Rao, B.V., 2001. Development of short-duration chickpea for the sub-tropics. ICPN 8, 7-8.

Ludlow, M.M., Muchow, R.C., 1990. Critical evaluation of traits for improving crop yields in water-limited environments. Adv. Agron. 43, $107-153$.

Mathews, R.B., Harris, D., Rao, R.C.N., Williams, J.H., Wadia, K.D.R., 1988. The physiological basis for yield differences between four genotypes of groundnut (Arachis hypogaea) in response to drought. 1. Dry matter production and water use. Exp. Agric. 24, 191-202.

Saxena, N.P., 1987. Screening for adaptation to drought: case studies with chickpea and pigeonpea. In: Saxena, N.P., Johansen, C. (Eds.), Adaptation of chickpea and pigeonpea to abiotic stresses. Proceedings of consultant's workshop, International Crops Research Institute for the Semi-Arid Tropics, Patancheru 502324, Andhra Pradesh, India, pp. 63-76.

Saxena, N.P., 2003. Management of drought in chickpea-a holistic approach. In: Saxena, N.P. (Ed.), Management of Agricultural Drought. Oxford \& IBH publishing Co. Pvt. Ltd., New Delhi, pp. 103-122.

Saxena, N.P., Johansen, C., 1990. Chickpea ideotypes for genetic enhancement of yield and yield stability in South Asia. In: van Rheenen, H.A., Saxena, M.C. (Eds.), Chickpea in the Nineties: Proceedings of the Second International
Workshop on Chickpea Improvement. 4-8 December 1989, ICRISAT Center, Patancheru 502324, A.P., India, pp. 81-85.

Saxena, N.P., Krishnamurthy, L., Johansen, C., 1993. Registration of a droughtresistant chickpea germplasm. Crop Sci. 33, 1424.

Saxena, N.P., Sethi, S.C., Krishnamurthy, L., Johansen, C., Haware, M.P., 1995. Physiological approaches to genetic improvement of drought resistance in chickpea. In: Physiological Approaches to genetic Improvement of Drought Tolerance in Chickpea: Proceedings of the Inter Drought 95, Montpellier, France, 31st August-2nd September 1995, Genetique et Amelioration des Plantes, INRA, Montpellier cedex, pp. 1-6.

Schneider, K.A., Rosales-Serna, R., Ibarra-Perez, F., Cazares-Enriquez, B., Acosta-Gallegos, J.A., Ramirez-Vallejo, P., Wassimi, N., Kelly, J.D., 1997. Improving common bean performance under drought stress. Crop Sci. 37, 43-50.

Singh, S., Gowda, C.L.L., Sethi, S.C., Dasgupta, T., Smithson, J.B., 1992. Genetic analysis of agronomic characters in chickpea I. Estimates of genetic variances from diallel mating designs. Theor. Appl. Genet. 83, 956-962.

Subbarao, G.V., Chauhan, Y.S., Johansen, C., 2000. Patterns of osmotic adjustment in pigeonpea-its importance as a mechanism of drought resistance. Eur. J. Agron. 12, 239-249.

Torres, A.M., Moreno, M.T., Cubero, J.I., 1993. Genetics of six components of autofertility in Vicia faba. Plant Breed. 110, 220-228.

Turner, N.C., Wright, G.C., Siddique, K.H.M., 2001. Adaptation of grain legumes (pulses) to water-limited environments. Adv. Agron. 71, 193-231.

Upadhyaya, H.D., Bramel, P.J., Singh, S., 2001. Development of a chickpea core subset using geographic distribution and quantitative traits. Crop Sci. 41, 206-210.

Upadhyaya, H.D., Nigam, S.N., 1998. Epistasis for vegetative and reproductive traits in peanut. Crop Sci. 38, 44-49.

Upadhyaya, H.D., Ortiz, R., 2001. A mini core subset capturing diversity and promoting utilization of chickpea genetic resources in crop improvement. Theor. Appl. Genet. 102, 1292-1298.

White, J.W., Castillo, J.A., 1988. Studies at CIAT on mechanisms of drought tolerance in beans. In: White, J.W., Hoogenboom, G., Ibarra, F., Singh, S.P. (Eds.), Research on Drought Tolerance in Common Bean. Centrol Internacional de Agricultura Tropical, Cali, pp. 146-151.

Wright, G.C., Hubick, K.T., Farquhar, G.D., 1991. Physiological analysis of peanut cultivar response to timing and duration of drought stress. Aust. J. Agric. Res. 42, 453-470. 